\title{
ORGANISASI KURIKULUM \\ BAHASA ARAB
}

\author{
RAHNANG \\ Penulis adalah Pengajar IAIN Pontianak, Fakultas Tarbiyah \& \\ Ilmu Keguruan, Jurusan Pendidikan Bahasa Arab (PBA)
}

\begin{abstract}
ABSTRAK
In the learning process, the curriculum has a very important role, especially for teachers and students. Therefore, to make it easier to implement the curriculum, especially in learning the Arabic language, then it is divided into several systems.

In the Arabic language learning, the curriculum system division is then called curriculum organization which consists of two systems i.e. Nazhariyatul Furu' and Nazhariyatul Wahdah. Curriculum organization is a framework or pattern of the lessons arranged based on specific purposes of educational programs to achieve. In addition, the principle of curriculum organization is that it is arranged to facilitate the process of learning for teachers and students so as to achieve educational purposes effectively and optimally.
\end{abstract}

Keywords: Arabic Curriculum Organization, Nazhariyatul Furu', Nazhariyatul Wahdah

\section{Pendahuluan}

Bahasa merupakan alat yang sangat penting bagi seseorang, apapun jabatan dan kedudukannya, dari rakyat kecil sampai ke tingkat rakyat besar dalam strata socialnya. Fungsi bahasa sangat banyak, di antaranya sebagai alat komunikasi, interaksi, peyampaian dan penerimaan informasi, dan sebagai alat untuk proses pemahaman sebuah kajian keilmuan.

Bahasa Arab bagi masyarakat Indonesia khususnya umat Islam merupakan bahasa asing. Meskipun tergolong bahasa asing, bahasa ini menjadi begitu sangat penting. Alasannya adalah bahasa Arab mempunyai keterkaitan erat dengan kebutuhan peribadatan kepada Tuhan terutama menjalankan rukun Islam yang kedua, yakni shalat. Dalam shalat bahasa yang digunakan adalah bahasa
Arab. ${ }^{1}$ Selain bahasa Arab sebagai bahasa komunikasi spiritual, bahasa Arab juga merupakan sumber informasi kajian keilmuan (bidang Hukum Islam dan Tauhid) serta keilmuan lainnya. Jadi, apabila bahasa Arab dianggap sebagai sumber, pantaslah kiranya kurikulum pembelajaran bahasa Arab mengarah kepada empat kemahiran dasar dalam مهارة الإستماع، مهارة الكلام، berbahasa, yakni

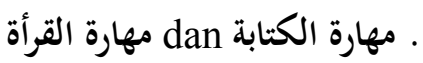

Apabila ingin mengadakan pembaharuan dalam pendidikan, kita harus memperhatikan kurikulum yang sudah dirumuskan. Kalau pendidikan diperbaharui, maka sudah barang tentu (otomatis) kurikulumnya pun harus

1 Wajiz Anwar, Pengajaran Bahasa Arab di Indonesia (Majalah al-Jamiah IAIN Sunan Kalijaga Yogyakarta, No. 2, 1971), hlm. 48. 
berubah. Kita tidak bisa mengadakan pembaharuan tanpa perubahan pada kurikulum. Keberadaan kurikulum sebagai program pendidikan yang telah direncanakan secara sistematis mengemban peranan yang sangat penting.

Begitu besarnya peranan kurikulum terrhadap maju mundurnya pendidikan. Maka lembaga pendidikan khususnya guru bahasa Arab dituntut untuk segera melakukan inovasi-inovasi pengembangan kurikulum (kurikulum tidak boleh statis tetapi harus dinamis) seiring tuntutan dunia global yang terus mengalami perubahan dan perkembangan.

\section{SEJARAH PERKEMBANGAN KURIKULUM BAHASA ARAB DI INDONESIA}

Bagaikan jiwa dan jasmani itulah ungkapan yang tepat antara hubungan kurikulum dengan pembelajaran, keduanya mempunyai hubungan yang sangat erat. Pembelajaran bahasa Arab akan mengalami kegagalan minimal kurang berhasil tanpa kurikulum yang memadai, begitu juga sebaliknya.

Agama Islam masuk di Indonesia khususnya di tanah Jawa sejak tahun $1406 .{ }^{2}$ Dalam sejarahnya, terdapat dua bentuk proses pembelajaran bahasa Arab yang dilakukan untuk mempermudah penyebaran agama Islam. Bentuk Pertama, pembelajaran dilakukan dalam bentuk pengajian seperti yang tampak di surausurau atau masjid-masjid yang ada sekarang ini atau di rumah kyai-kyai di mana diajarkan adalah bagian dari al-Quran. Bentuk pembelajaran bahasa Arab ini merupakan bentuk tertua dan pertama kali. ${ }^{3}$

\footnotetext{
${ }^{2}$ H. Fakhruddin, Teknik Pengembangan Kurikulum Pengajaran Bahasa Arab (Yogyakarta: Global Pustaka Utama, 2006), hlm. 5. Lebih jelas lihat, Schrieke, B. J. O, Het Boek Van Bonang (Leiden: Disertasi Rijksuniv, 1916), hlm. 30.

${ }^{3}$ Fakhruddin, Kurikulum Pengajaran Bahasa Arab, hlm. 7 .
}

Bentuk Kedua, pembelajaran bahasa Arab merupakan pengembangan kurikulum yang erat kaitannya dengan pelajaran Agama Islam yang diberikan kepada para pemuda yang merasa haus pengetahuan agama Islam pada tingkat yang lebih tinggi yakni dilaksanakan di pesantren-pesantren yang dipimpin oleh kyai. Pada masa itu pelajaran bahasa Arab seperti Nahwu, Sharf, Balaghah, Insya', Mantiq, Arud, dan sebagainya, ilmu-ilmu tersebut merupakan kunci utama dalam mengetahui ilmu pengetahuan agama Islam. Adapun ilmu agama yang diajarkan adalah Fiqih, 'Aqaid, Hadis, Tafsir. Adapun corak pengajaran dan ilmu pengetahuan yang diberikan kepada santri masih bersifat tradisional, yakni semuanya masih sangat tergantung pada kyai.

Dalam proses pembelajarannya, metode yang digunakan adalah metode sorogan (pada taraf rendah pelajaran diberikan secara perseorangan, caranya santri maju kehadapan guru seorang demi seorang, ia membaca salah satu kalimat lalu diterjemahkan). ${ }^{4}$ Santri menyimak dengan memberi tanda-tanda pada setiap kata atau kalimat yang diterangkan. Pekerjaan tersebut dalam bahasa Jawa dikenal dengan ngesahi' artinya guru telah menganggap sah terhadap buku atau kitab yang telah diajarkan kepada murid dan ia telah menerimanya. $^{5}$

Kedudukan guru pada masa itu sangat tinggi, guru mempunyai hak untuk mengesahkan atau tidaknya sesuatu ilmu. Sesuatu ilmu belum dianggap sempurna apabila belum digurukan. Dengan demikian jika terdapat seseorang mengamalkan ilmu tanpa mendapat keterangan dari guru dikhawatirkan pengamalannya tidak tepat dan tidak sesuai dengan kaidah syar'i, sebab kitab-kitab yang digunakan pada umumnya berbahasa Arab yang memungkinkan akan terjadinya misunderstanding.

\footnotetext{
${ }^{4}$ Ibid., hlm. 6.

${ }^{5}$ Ibid., hlm. 6.
} 
Perkembangan selanjutnya dunia pesantren mengalami kemajuan, para kyai sudah mulai berfikir modern sehingga berbagai kemajuan dapat dicapai. Sebelumnya, kurikulum bahasa Arab hanya berisi mengeja dan membaca al-Quran, kemudian berkembang dengan mengguna media-media sederhana misalnya papan tulis, bangku, dan sebagainya. Taraf kurikulum tersebut terus berkembang hingga sekarang, terbukti dalam proses pembelajarannya sudah menggunakan media-media modern. ${ }^{6}$

Jika dicermati secara seksama dapat dilihat tujuan dari kedua bentuk pembelajaran bahasa Arab tersebut bukanlah mengarah kepada belajar bahasa Arab secara langsung. Tujuan pertama hanya mengarahkan kepada kemampuan membaca al-Quran sedangkan bentuk yang kedua bertujuan untuk memahami ajaran ajaran Agama Islam. $^{7}$ Oleh karenanya pengetahuan bahasa Arab santri dalam berbicara untuk mengungkapkan ucapan dan mengemukakan maksud dengan berbahasa Arab sangat pasif. ${ }^{8}$

Berangkat dari problem yang dialami dalam berbahasa Arab. Banyak pemudapemuda Nusantara yang hijrah ke Timur Tengah untuk belajar bahasa Arab secara langsung. Dengan tujuan agar bisa berbahasa Arab secara aktif sehingga ilmu yang mereka miliki khususnya tentang bahasa Arab menjadi lebih mendalam.

Sekembalinya para pemuda tersebut dari Timur Tengah ternyata membawa angin segar bagi pembelajaran bahasa Arab. Di mana proses pembelajaran yang

\footnotetext{
${ }^{6}$ Ibid., hlm. 5. Lebih jelas lihat, Abu Bakar. A, Sejarah hidup K. H. A. Wahid Hasyim (Jakarta: Panitia Peringatan Alm K. H. A. Wahid Hasyim, 1957), hlm. 49.

${ }^{7}$ Kadangkala santri hanya bisa membaca kitab-kitab yang telah diajarkan oleh kyainya dalam pondok pesantren.

${ }^{8}$ Problem ini (pasif dalam berbahasa Arab secara lisan) masih dirasakan oleh siswa hingga saat ini, terutama siswa yang hanya mendapati pembelajaran bahasa Arab (bukan dari pesantren bahasa).
}

berlangsung menggunakan bahasa Arab, ${ }^{9}$ yakni guru memprioritas pada keterampilan berbicara dengan menggunakan bahasa Arab langsung kepada santri. Pembelajaran demikian adalah bentuk yang ketiga seperti yang dilakukan oleh beberapa pondok pesantren di antaranya pesantren Modern Gontor (Dar as-Salam) dan sekolah-sekolah Madrasah Diniyah lainnya. ${ }^{10}$

Selanjutnya muncul bentuk yang keempat sebagai pengembangan dari bentuk I, II dan III yang telah dipaparkan di atas. Bentuk keempat tersebut ialah all function ${ }^{11}$ dengan melihat dari segi fungsinya yang tidak hanya sekedar untuk mengetahui bahasa dan agama saja tetapi lebih dari itu, yakni berkomunikasi dengan dunia internasional dalam era globalisasi dalam seghala aspeknya. Bentuk ini pernah diperkenalkan oleh Abul Abbas alMubarrad (pakar ilmu bahasa mazhab Bazrah, 826-898 M) dalam kitabnya alKamil.

\section{ORAGANISASI KURIKULUM}

\section{Pengertian}

Organisasi kurikulum adalah struktur program yang berupa kerangka program-program pengajaran yang akan disampaikan kepada siswa. ${ }^{12}$. Nasutian, memberikan pengertian bahwa organisasi

\footnotetext{
9 Siswa diajak langsung berbicara dengan menggunakan bahasa Arab dalam proses pembelajaran bahasa disebut al-Thariqah alMubasyirah. Cara yang dilakukan oleh para kyai muda tersebut membawa kesuksesasan besar dan ini telah diakui oleh para pengajar bahasa Arab dari berbagai kawasan dunia. Metode ini muncul sebagai reaksi ketidakpuasan terhadap hasil belajar bahasa dari metode sebelumnya, yaitu metode tarjamah yang dipandang memperlakukan bahasa sebagai sesuatu yang mati. Lihat, Ibrahim Badri, Thuruqul al- 'Ammah fi-Tadris al-Lughoh al-Ajnabiyah (Arab Saudi: Li ad-Daurat at-Tarbiyah al-Mukatsafah,....), hlm. 6 .

${ }^{10}$ Fakhruddin, Kurikulum Pengajaran Bahasa Arab, hlm. 14.

${ }^{11}$ Ibid., hlm. 14

${ }^{12}$ Ahmad dkk, Pengembangan Kurikulum (Bandung: C.V. Putaka Setia, 1990),
} 
kurikulum adalah pola atau bentuk bahan pelajaran yang disusun yang bertalian erat dengan tujuan program pendidikan yang hendak dicapai. ${ }^{13}$ Sejalan dengan pendapat di atas, Muhammad Ali, menyatakan bahwa organisasi kurikulum merupakan suatu cara menyusun bahan-bahan atau pengalaman belajar yang ingin dicapai. ${ }^{14}$

Secara umum beberapa pendapat di atas menyatakan bahwa organisasi kurikulum bertujuan untuk mempermudahkan siswa dalam belajar, karena dalam organisasi kurikulum mencoba untuk mewujudkan apa yang diketahui tentang teori, konsep, pandangan tentang pendidikan, perkembangan siswa dan kebutuhan masyarakat.

Kurikulum organisasi mempunyai peran untuk menentukan apa yang akan dipelajari, kapan waktu yang tepat untuk mempelajarinya, keseimbangan bahan pelajaran dan keseimbangan antara aspekaspek pendidikan yang akan disampaikan.

Setiap bentuk organisasi kurikulum mewarnai jenis bahan, urutan serta metode mempelajarinya. terdapat dua bentuk organisasi kurikulum, yakni:

a. Kurikulum yang menggunakan organisasi berpusat pada mata pelajaran. Pada bentuk kurikulum ini bahan diorganisasi dengan mengambilnya dari mata pelajaran yang menjadi isi kurikulum. Kurikulum semacam ini biasanya lebih menekankan pada pendidikan intelektual. Kurikulum ini termasuk organisasi kurikulum horizontal. ${ }^{15}$

\footnotetext{
${ }^{13}$ Nasution, Asas-Asas Kurikulum, cet. VI (Jakarta: PT. bumi Aksara, 2005), hlm. 176.

14 Muhammad Ali, Pengembangan Kurikulum di Sekolah, Cet. IV (Bandung: Sinar Baru Algesindo, 2005), hlm. 108.

${ }^{15}$ Organisasi kurikulum horizontal, yaitu struktur yang berhubungan dengan masalah pengorganisasian kurikulum dalam bentuk penyusunan bahan-bahan pengajaran yang akan disampaikan. Bentuk-bentuk penyusunan mata pelajaran tersebut itu dapat secara terpisah (correlated), atau penyatuan seluruh mata pelajaran
}

b. Kurikulum yang menggunakan organisasi berpusat pada kegiatan. Bentuk kurikulum ini bahan diorganisasi bersumber pada pengalaman atau kegiatan. Tekanan kurikulum semacam ini adalah pembentukan pribadi secara utuh. Kurikulum ini termasuk organisasi kurikulum vertical. ${ }^{16}$

Ada beberapa kriteria dalam merumuskan organisasi kurikulum yang efektif. Menurut Oemar Hamalik, yang perlu diperhatikan dalam penyusunan organisasi kurikulum, yaitu: ruang lingkup (scope), urutan (sequance) dan penempatan bahan (grade placement). ${ }^{17}$

a. Ruang lingkup bahan (scope) adalah keseluruhan materi pelajaran dan pengalaman yang akan diberikan dari suatu bidang studi atau dari sesuatu pokok bahasan tertentu. Selain itu sesuatu pokok bahasan dan atau sub pokok bahasan juga mengandung ruang lingkupnya tersendiri. Ruang lingkup bahan itu merupakan perincian dari pada pokok atau topic tersebut. Kejelasan tentang perincian bahan tersebut dapat kita peroleh dari dalam buku paket atau sumber pokok dari pelajaran yang telah ditentukan.

b. Urutan (sequance) adalah penyusunan bahan pelajaran menurut aturan tertentu secara berurutan, urutan bahannya disusun sedemikian rupa agar menunjukkan sistematika dan memudahkan penyampaian maupun penangkapan oleh para siswa.

(integrated). Tercakup pula di sini adalah jenis-jenis program yang dikembangkan di sekolah, yaitu program pendidikan umum, akademis, keguruan, keterampilan, dan lain-lain. Lihat, Ahmad, Pengembangan Kurikulum, hlm. 105.

${ }^{16}$ Organisasi kurikulum vertical, yaitu struktur berhubungan dengan pelaksanaan kurikulum di sekolah. Misalnya apakah kurikulum dilaksanakan dengan system kelas, tanpa kelas atau gabungan keduanya, dengan system waktu atau caturwulan. Ali, Kurikulum di Sekolah, hlm. 108.

${ }^{17}$ Oemar Hamalik, Pengembangan Kurikulum (Dasar-Dasar Perkembangannya) (Bandung: Mandar Maju, 1980), hlm. 103. 
c. Penempatan bahan (grade placement) adalah penempatan beberapa bahan pelajaran untuk kelas tertentu. Penempatan bahan pelajaran tersebut dihubungkan dengan ruang lingkup bahan dan diserasikan dengan urutan bahan pelajaran.

Sedangkan Tayler merumuskan kriteria organisasi kurikulum yang efektif menjadi tiga, di antaranya adalah: ${ }^{18}$

a. Berkesinambungan (continuity)

b. Berurutan (sequence)

c. Keterpaduan (integrated)

Ketiga kriteria menurut Tayler, merupakan petunjuk dalam membuat organisasi kurikulum. Hal ini tidak terikat pada suatu bentuk organisasi kurikulum apapun yang digunakan. Pada dasarnya semua organisasi kurikulum mempunyai bahan yang akan dijadikan isi.

Bila dihubungkan denga konsep Taksonomi Bloom, unsur-unsur yang diorganisaikan meliputi tiga hal, yaitu konsep berhubungan dengan pengetahuan, nilai-nilai berhubungan dengan sikap dan keterampilan berhubungan dengan keterampilan. ${ }^{19}$ Jadi, bila akan dilakukan organisasi dalam pelajaran Bahasa Arab, maka isi pelajarannya meliputi konsep (pengetahuan), nilai-nilai yang perlu dimiliki oleh siswa, serta keterampilanketerampilan yang perlu dikembangkan.

Untuk memperoleh organisasi kurikulum yang efektif perlulah diperhatikan, bahwa kriteria tersebut dapat diterapkan dalam mengorganisasi kegiatan mempelajari bahan-bahan tersebut. Oleh Karena itu setiap pegembang kurikulum sepatutnya dapat melihat berbagai keunggulan maupun kelemahan yang dimiliki oleh masing-masing bentuk organisasi, agar dapat dicarikan suatu cara mengurangi kelemahan bila suatu bentuk tertentu terpilih.

\footnotetext{
${ }^{18}$ Lihat, Ali, Kurikulum di Sekolah, hlm. 109.

${ }^{19}$ Ibid., hlm. 110-111.
}

\section{Prinsip-Prinsip Organisasi Kurikulum}

Kriteria yang dipergunakan untuk memilih atau menilai isi kurikulum seperti yang telah penulis kemukan di atas sesungguhnya dapat juga digunakan dalam penyusunan organisasi kurikulum. Selain itu masih ada beberapa petunjuk atau prinsip yang dianjurkan dipergunakan dalam dalam penyusunan organisasi kurikulum. Prinsip-prinsip ini dikembangkan dalam penyusunan Kurikulum Sekolah Menengah di Amerika Serikat, yang mungkin dalam beberapa hal dapat pula diterapkan di negara kita, yakni sebagai berikut: ${ }^{20}$

a. Susun ruang lingkup dan urutan kurikulum secara fleksibel.

b. Susunlah suatu bentuk pengalaman pendidikan sambil memperhatikan pelayanan terhadap minat dan kebutuhan yang khusus.

c. Menyelaraskan dengan cara belajar siswa.

d. Susunlah atas dasar tujuan yang telah ditentukan dan susunlah evaluasi terhadap pertumbuhan dan perkembangan para siswa sejalan dengan tujuan tersebut.

e. Pertimbangkan individu para siswa dan libatkan mereka dalam perencanaan kurikulum dan kehgiatan belajar secara aktip.

f. Kaitkan dengan bentuk pendidikan secara menyeluruh guna menciptakan suasana pelajar yang menyenangkan baik di dalam sekolah maupun di dalam masyarakat.

\section{Organisasi Kurikulum Bahasa Arab}

Penyusunan kurikulum sangatlah tergantung pada asas organisatoris, yakni bentuk penyajian bahan pelajaran atau organisasi kurikulum. Dalam studi tentang kurikulum dikenal beberapa bentuk organisasi kurikulum. Bentuk tersebut memiliki ciri-ciri tersendiri dan nampaknya

\footnotetext{
${ }^{20}$ Hamalik, Pengembangan Kurikulum, hlm. 105.
} 
mengalami proses pengembangan secara berurutan sejalan dengan penemuanpenemuan baru dalam ilmu kurikulum.

Menurut Busyairi, ada dua organisasi kurikulum bahasa Arab, yaitu: ${ }^{21}$

a. نظرية الفروع yaitu organisasi kurikulum pengajaran bahasa Arab yang membagibagi pelajaran bahasa Arab kedalam berbagai cabang dan setiap cabang mempunyai rencana pelajaran sendiri (syllabus), buku dan jam pelajaran sendiri. Masing masing pelajaran berjalan dengan batas-batasnya, terpisah satu sama lain. ${ }^{22}$

Dalam defenisi lainnya teradapat persamaan antara نظرية الفروع dengan

Subject-mater curriculum. Subject-mater curriculum merupakan organisasi tertua dan banyak digunakan di banyak negara. Bentuk kurikulum ini tergolong dan dinilai sebagai bentuk tradisional. Kurikulum ini diterapkan pada sekolahsekolah sampai munculnya kurikulum 1968 dan kurikulum 1975. Sejak permulaan abad ke-20 terutama Amerika Serikat muncul beberapa jenis organisasi kurikulum yang baru sebagai reaksi terhadap organisasi kurikulum tersebut. ${ }^{23}$ Subject-mater curriculum yaitu organisasi kurikulum yang terdiri atas mata pelajaran-mata pelajaran yang terpisah-pisah yang satu dengan yang lainnya. ${ }^{24}$ Senada dengan pendapat di atas, pada bentuk ini bahan dikelompokkan pada mata pelajaran yang sempit, di mana antara mata

\footnotetext{
${ }^{21}$ Busyairi Madjidi, Metodologi Pengajaran Bahasa Arab (Penerapan Audio lingual Method dalam All in One System) (Yogyakarta: Sumbangsih Offset, 1994), hlm. 7.

${ }^{22}$ Muhammad Sholeh Samak, Fannu Tadris (Kairo: Darul Fikr al-Arab: 1998), hlm. 52.

23 Nana Sudjana, Pembinaan dan Pengebangan Kurikulum di Sekolah, cet. V (Bandung: Sinar Baru Algesindo, 2005), hlm. 51.

${ }^{24}$ Nasution, Asas-Asas Kurikulum, hlm. 80.
}

pelajaran yang satu dengan yang lainnya menjadi terpisah-pisah. ${ }^{25}$

Menurut Tyler dan Alexander bahwa jenis organisasi kurikulum ini digunakan dengan school subject, sejak beberapa abad hingga saat ini masih banyak dipergunakan diberbagai lembagalembaga pendidikan. Organisasi kurikulum ini terdiri dari beberapa mata pelajaran, yang tujuannya adalah siswa harus menguasai bahan dari setiap mata pelajaran yang telah ditentukan secara logis, sistematis, dan mendalam. ${ }^{26}$

Dari beberapa pendapat di atas, dapat disimpulkan sementara bahwa organisasi kurikulum ini merupakan organisasi isi pendidikan dalam bentuk mata pelajaran yang disajikan dan diberikan kepada siswa secara terpisah-pisah Konsekuensinya, siswa harus semakin banyak mengambil mata pelajaran.

Pada organisasi kurikulum ini mata pelajaran dapat menetapkan syarat-syarat minimum yang harus dikuasai anak, sehingga anak didik bisa naik kelas. Biasanya mata pelajaran dan textbook merupakan alat dan sumber utama pelajaran. Subject- curriculum terdiri dari mata pelajaran (subject) yang terpisah pisah, dan subject itu merupakan himpunan pengalaman dan pengetahuan yang diorganisasikan secara logis dan sistematis oleh oleh para ahli kurikulum (experts). ${ }^{27}$

\section{b. Kelebihan نظرية الفروع}

a) Organisasi kurikulum ini sederhana dan mudah direncanakan.

b) Sistem ini memudahkan guru untuk lebih menfokuskan pada satu

25 Syafruddin dan Basyiruddin Usman, Guru Profesional dan Implementasi Kurikulum, cet. I (Jakarta:Ciputat Pers, 2002), hlm. 44.

26 Abdullah Idi, Pengembangan Kurikulum Teori dan Praktik, cet. II (Jogjakarta: Ar-Ruzz Media, 2007), hlm. 142.

${ }^{27}$ Idi, Pengembangan Kurikulum Teori dan Praktik, hlm. 142 . 
bidang pelajaran. Misalnya pembelajaran nahwu atau sharf saja.

c) Sistem ini merupakan alternatif bagi guru yang pasif berbahasa Arab ketika hendak mengajarkan tata bahasa Arab.

d) Guru dapat memperdalam masalah-masalah yang harus dipelajari oleh siswa sesuai dengan bidang studi masing-masing, dan lainlainnya.

\section{c. Kelemahan نظية الفروع}

a) Sistem ini tidak sama dan seimbang. Kadang-kadang guru hanya mementingkan tata bahasa saja dan kurang mementingkan keterampilan yang lain seperti membaca. Akibatnya siswa pintar ilmu nahwu tetapi tidak bisa membaca dan bercakap-cakap dalam bahasa Arab.

b) Menurut teori ini bahasa itu dipecah-pecah, sehinga rusak inti sari bahasa dan keluar dari tabiaat aslinya. ${ }^{28}$

c) Kesempatan siswa untuk menguasai empat keterampilan bahasa menjadi berkurang.

d) Terkadang terjadi tumpang tindih materi yang diajarkan oleh seorang guru dengan guru lainnya, dan lain-lainnya.

d. نظرية الوحده adalah sistem pengajaran bahasa yang memandang kepada bahasa itu sendiri sebagai bahasa, bahwa bahasa sebagai alat komunikasi antara manusia merupakan keutuhan dan kebulatan, kait mengait atau saling berhubungan, tidak berbagi-bagi dan berbeda-beda. ${ }^{29}$

Sedangkan teori wahdah memiliki persamaan pandangan dengan

\footnotetext{
${ }^{28}$ Mahmud, Metodik, hlm. 28.

${ }^{29}$ Teori ini pernah diperkenalkan oleh Abul Abbas al-Mubarrad (pakar ilmu bahasa mazhab Bazrah, 826-898 M) dalam kitabnya al-Kamil. Madjidi, Metodologi Pengajaran Bahasa Arab, hlm. 10.
}

Correlated curriculum. Correlated curriculum adalah bentuk kurikulum yang disusun dengan tujuan supaya ada hubungan antara mata pelajaran yang satu dengan yang lain. ${ }^{30}$ Correlated curriculum merupakan suatu bentuk kurikulum yang menunjukkan adanya suatu hubungan (korelasi) antara satu mata pelajaran dengan mata pelajaran yang lainnya, tetapi tetap memperhatikan karakteristik tiap bidang studi tersebut. ${ }^{31}$ Sedangkan pendapat lain yang senada menyatakan, correlated curriculum mengandung makna bahwa sejumlah mata pelajaran dihubungkan antara yang satu dengan yang lain, sehingga ruang lingkup bahan yang tercakup semakin luas. $^{32}$ Bentuk kurikulum ini adalah usaha untuk mengurangi kelemahan yang ada pada subject-mater curriculum. Sistem ini disebut juga dengan metode unit atau Unit Method. Unit artinya bagian-bagian yang memiliki kesatuan lengkap dan bulat (terpadu). ${ }^{33}$ System ini dalam bahasa Inggris disebut Ingtegrated System/All in One system. Terori kesatuan dalam pembelajaran bahasa ialah kita memandang kepada bahasa sebagai satu kesatuan yang saling berkaitaan dan berhubungan erat, dan tidak memandangnya sebagai bagianbagian yang terpisah-pisah dan berbedabeda. ${ }^{34}$

Usaha menintegrasikan bahan pelajaran dari berbagai materi pelajaran menghasilkan kurikulum terpadu. Integrasi ini tercapai dengan memusatkan pelajaran pada masalah tertentu yang memerlukan

\footnotetext{
${ }^{30}$ Nasution, Asas-Asas Kurikulum, hlm. 80.

31 Basyiruddin Usman, Guru Profesional dan Implementasi Kurikulum, hlm. 46.

${ }^{32}$ Ibid., hlm. 46.

33 Tayar Yusuf dan Syaiful Anwar, Metodologi Pengajaran Agama dan Bahasa Arab, Cet. II (Jakarta: PT. Raja Grafindo Persada, 1997), hlm. 172 .

34 Ahmad Fuad Efendy, Metodologi Pengajaran Bahasa Arab (Malang: Penerbit Miskat, hlm. 79.
} 
pemecahannya dengan bahan dari segala macam matapelajaran yang diperlukan. Bahan mata pelajaran menjadi instrumental dan fungsional untuk memecahkan masalah-masalah tersebut. Dengan system ini batas-batas anatar matapelajaran dapat ditiadakan.

Bentuk kurikulum ini membuka kesempatan yang lebih besar untuk mengadakan kerja kelompok, memanfaatkan masyarakat dan lingkungan sebagai sumber belajar, memperhatikan perbedaan individual, serta dapat melibatkan siswa dalam perencanaan pelajaran. Selain memperoleh sejumlah pengetahuan secara fungsional, kurikulum ini mengutamakan proses belajarnya.

Menurut teori ini dibuat suatu judul, atau tema bacaan untuk menjadi pokok bahasan atau pusat semua pelajaran, lalu dari judul atau tema ini dibuat bacaan pula (muthala'ah), percakapan, (hiwar), tata bahasa (nahmu/sharf), mengarang terarah (insya' muwajjah), dikte (imla') dan latihan-latihan bahasa gramatikal dan kegiatan proses belajar mengajar bahasa. ${ }^{35}$

Oleh karena itulah, teori ini menjadi sangat dominan digunakan pada masamasa awal pengajaran bahasa dan penyusunan buku-buku tentang bahasa. Kitab al-Kamil karya al-Mubarrad termasuk buku yang dinilai sebagai buku percontohan yang dalam penyususnan menggunakan teori atau cara ini. Dalam buku ini ditampilkan teks (nash), kemudian dianalisis dari aspek kebahasaannya, struktur nahwu dan sharfnya, serta aspek-aspek lainnya.

Teori kesatuan ini tidak mengenal adanya pengkhususan jam pelajaran tertentu untuk masing-masing jenis mata pelajaran bahasa, yang ada hanya jam pelajaran untuk bahasa Arab secara

35 Ibid, lihat Madjidi, Metodologi Pengajaran Bahasa, hlm. 10. Lihat pula Junus, Methodik khusus Bahasa, hlm. 26. umum. Teori ini terkesan sesuai dengan realitas penggunaan bahasa yang memadukan berbagai unsur dan keterampilan berbahasa secara utuh baik penggunaan bahasa secara lisan atau tulisan.

\section{نظ نظية الوحده elebihan}

a) Mempermudah guru untuk mengarahkan siswa kepada empat keterampilan berbahasa.

b) Prsoses pembelajaran lebih terfokus pada metode mubasyarah.

c) Siswa lebih aktif dan fokus terhadap pelajaran bahasa Arab itu sendiri.

d) Tata bahasa yang digunakan disesuaikan pada materi yang diajarkan.

e) Mempermudah guru untuk melakukan evaluasi terhadap materi yang akan diujikan, dan lain-lainnya.

\section{f. Kelemahan نظرية الوحده}

a) Pengetahuan siswa dalam tata bahasa (nahwu dan sharf) kurang mendalam.

b) Guru kesulitan untuk meramu semua pelajaran yang berkaitan dengan bahasa menjadi satu kesatuan utuh dalam bahasa Arab.

c) Bentuk ini membuat guru yang pasif berbicara bahasa Arab kesulitan dalam mengajarkannya.

d) Alokasi waktu pembelajaran bahasa Arab kurang maksimal, dan lainlainnya.

Walaupun terdapat perbedaan pada kedua system ini, tetapi masih dapat dilakukan kolaborasi bahkan dapat diambil unsur-unsur keistimewaan masing-masing, bilamana system ini tidak dipegang secara ekstrem.

Sistem Furu'iyyah agar tidak memandang masing-masing cabang berdiri sendiri, lepas dari cabang lainnya dan agar memandang pemecahan ke dalam cabang-cabang itu 
sebagai masalah teknis operasional untuk memudahkan jalan pengajaran saja. Sedangkan system wahdah tetap memperhatikan tujuan instruksional khusus tiap cabang itu, tiap-tiap cabang itu sebenarnya saling berkaitan, bantumembantu dengan cabang lainnya untuk mencapai tujuan pokok dari bahasa, yakni sarana komunikasi antar sesama.

\section{PENUTUP}

Organisasi kurikulum adalah salah satu cara untuk menyusun bahan atau pengalaman belajar yang ingin dicapai. Setiap organisasi kurikulum mempunyai kelebihan dan kelemahan. Untuk itu perlu dipilih organisasi kurikulum yang efektif dengan kriteria berkesinambungan, berurutan dan terpadu. ${ }^{36}$

Demikianlah paparan singkat organisasi kurikulum bahasa Arab. Semoga tulisan ini dapat menambah pengetahuan bagi kita semua. Saran dan masukkan sangat diharapkan untuk perbaikan. Wallahu 'alam.

\section{DAFTAR PUSTAKA}

Ali, Muhammad, Pengembangan Kurikulum di Sekolah, Bandung: Sinar Baru Algesindo, 2005.

dkk, Ahmad, Pengembangan Kurikulum, Bandung: C.V. Putaka Setia, 1990.

Efendy, Ahmad Fuad, Metodologi Pengajaran Bahasa Arab, Malang: Penerbit: Mistkat, 2005.

Hamalik, Oemar, Pengembangan Kurikulum (Dasar-Dasar Perkembangannya), Bandung: Mandar Maju, 1980.

\footnotetext{
36 Idi, Pengembangan Kurikulum Teori dan Praktik,
} hlm. 111.
Idi, Abdullah, Pengembangan Kurikulum Teori dan Praktik, Jogjakarta: ArRuzz Media, 2007.

Madjidi, Busyairi, Metodologi Pengajaran Bahasa Arab (Penerapan Audio lingual Method dalam All in One System), Yogyakarta: Sumbangsih Offset, 1994.

Muhammad Rohman, Kurikulum

Berkarakter, Jakarta: Prestasi Pustakaraya, 2012

Nasution, Asas-Asas Kurikulum, Jakarta: PT. bumi Aksara, 2005.

Samak, Muhammad Sholeh Fannu Tadris, Kairo: Darul Fikr al-Arab: 1998.

Sudjana, Nana, Pembinaan dan Pengebangan Kurikulum di Sekolah, Bandung: Sinar Baru Algesindo, 2005.

Tayar Tusuf dan Saiful Anwar, Metodologi Pengajaran Agama Dan Bahasa Arab, Cet. Ke II, Jakarta: PT. Grafindo Persada, 1997.

Usman, Basyiruddin dan Syafruddin Guru Profesional dan Implementasi Kurikulum, Jakarta: Ciputat Pers, 2002 